\title{
PIERĀDİŠANAS NASTA ATBILDĪBAS PAR VAINOJAMU RĪCĪBU PIEMĒROŠANĀ
}

\section{THE BURDEN OF PROOF IN DETERMINATION OF FAULT-BASED LIABILITY}

\author{
Edijs Brants, Mg. iur. \\ Latvijas Universitātes Juridiskās fakultātes doktorants
}

\begin{abstract}
Summary
In this article, the author analyses the burden of proof in determination of faultbased liability. The main focus is placed on the first prerequisite of civil liability fault, which can be defined as non-compliance of the factual conduct with the required standard of care (in form of negligence or intent). Currently, the aspect of burden of proof regarding fault is quite unclear in Latvian private law. Therefore, in this article the author answers the fundamental question: which party has the legal duty to prove the prerequisite "fault" (or its absence) according to the Civil Law? Additionally, the author will also outline the peculiarities of burden of proof in both tort law and contract law.
\end{abstract}

Atslēgvārdi: civiltiesiskā atbildība, vaina, vainas prezumpcija, pierādī̌sanas nasta.

Keywords: civil liability, fault, presumption of fault, burden of proof.

\section{Pierādī̌anas nastas sadalïjums Civillikumā}

Mūsdienās savu aktualitāti nav zaudējusi kādreiz prof. V. Bukovska izteiktā atziṇa, ka civilprocesa noteikumi par pierādīšanas pienākuma (onus probandi) sadalīšanu starp prāvniekiem ir visai trūcīgi. ${ }^{1}$ Tāpat jāpiekrīt savulaik A. Gasmana un A. Nolkena izteiktajai domai, ka civilprocesa pamatnoteikums - prasītājam jāpierāda sava prasība un atbildētājiem savas ierunas - ir tīri formāls, jo katrā konkrētā gadījumā vēl rodas jautājums par to, kādi fakti īsti jāpierāda prasìtājam un kādi atbildētājam. Kā norādījuši abi pieminētie autori, šis jautājums ietilpst materiālo tiesību laukā, un Baltijas guberņu Civīllikumos par to ir daudz noteikumu ${ }^{2}$. Iepriekš minētais pamatnoteikums mūsdienās ir palicis nemainīgs. Atbilstoši Civilprocesa likuma ${ }^{3}$ 93. panta pirmajai daḷai katrai pusei jāpierāda tie fakti, uz kuriem tā pamato savus prasījumus vai iebildumus. Prasìtājam jāpierāda savu prasījumu pamatotība. Atbildētājam jāpierāda savu iebildumu pamatotība. Lìdz ar to, lai noskaidrotu jautājumu, kam vispārējā (vainā balstītajā) atbildības modelī ir jāpierāda iespējamā tiesību aizskārēja vainojama rīcība jeb vaina (vai

\footnotetext{
Bukovskis V. Civīlprocesa mācības grāmata. Rīga: autora izdevums, 1933, 764. lpp.

Turpat.

3 Civilprocesa likums: LV likums. Pieṇemts 14.10.1998. Publicēts 03.11.1998. Latvijas Vēstnesis, 03.12.1998., Nr. 326/330; Latvijas Republikas Saeimas un Ministru Kabineta Ziṇotājs, Nr. 23.
} 
tās neesība), ir jāaplūko vispārējais materiālo tiesību regulējums, t. i., Civillikums ${ }^{4}$ (turpmāk - CL).

Apskatot CL Saistību tiesību daḷas trešās nodaḷas pirmo apakšnodaḷu "Neatl̦auta darbība un vainas pakāpes", iezīmējas divas normas, kas tiešā vai netiešā veidā regulē pierādišanas jautājumu. Pirmā no tām ir CL 1635. panta trešā daḷa: Ja šā panta otrajā daḷā minètā neatl̦autā darbība izpaudusies kā noziedzīgs nodarījums pret personas dzīvību, veselību, tikumību, dzimumneaizskaramību, brīvību, godu, cieņu vai pret ǵimeni, vai nepilngadīgo, pieņemams, ka cietušajam šādas darbības rezultātā ir nodarìts morālais kaitējums. Citos gadījumos morālais kaitējums cietušajam jāpierāda. Kā redzams, citētā norma neregulē vainojamas rīcības (vainas), bet gan morālā kaitējuma pierādīšanas aspektu, nosakot, kādos gadijumos tas ir pieņemams (prezumējams) un kādos tas ir jāpierāda cietušajam. Autors šajā ziṇā pievienojas Dr. iur. D. Oses izteiktajai atziṇai, ka [..] Civillikuma 1635. panta trešajā daḷā ir ietverta tikai morālā kaitējuma fakta prezumpcija, bet nevis civiltiesiskās atbildības prezumpcija. Atbilstoši Civillikuma 1635. panta trešajai daḷai civiltiesiskās atbildības kritērijus - tiesību aizskārēja prettiesisku, vainojamu rīcību un cēlonssakarību starp prettiesisko rīcību un kaitējumu - joprojām ir jāpierāda prasītājam, un par pierādìtu ir uzskatāms tikai morālā kaitējuma fakts. ${ }^{5}$

Otra norma ir CL 1644. panta pirmā dal̦a: Kas otram nodara kaitējumu bez l̦auna nolūka, ja viņš par šo kaitējumu ir vainojams, pielaiž neuzmanību. Rūpīgi izlasot šīs normas tekstu, var rasties iespaids, ka tā noteic vispārēju vainas prezumpciju. Proti, ja konkrētie lietas apstākḷi nenorāda uz l̦auna nolūka esību, tad sāk darboties prezumpcija, ka iespējamais tiesību aizskārējs pielaidis neuzmanību. Attiecīgi šāds pieṇēmums aizskārējam būtu jāatspēko. CL sistēmiskā skatījumā novērojams, ka prezumpcijas ielasīšanai šajā normā var kalpot arī apsvērums, ka CL Saistību tiesību daḷas trešās nodal̦as pirmajā apakšnodaḷā "Neatḷauta darbība un vainas pakāpes" vainas pakāpju definēšana tiek iesākta vispirms ar l̦aunu nolūku, tad pārejot pie rupjas neuzmanības un noslēdzot ar vieglu neuzmanību. Tas varētu vedināt domāt, ka ikvienā situācijā būtu jānovērtē situācija šādā secībā: l̦auns nolūks, rupja neuzmanība, viegla neuzmanība. Tomēr zināmu mulsumu rada panta piebilde, ka par šo kaitējumu tiesību aizskārējam tik un tā jābūt vainojamam.

Prof. K. Torgāns citēto normu apzīmē kā "īpatnēju noteikumu", piebilstot, ka Šì prezumpcija nav droša, jo nav tieši ierakstīta likumā. ${ }^{6}$ Šajā aspektā var tikai piekrist prof. K. Torgāna norādītajam, un šeit būtu vērā ṇemama šāda Augstākās tiesas Senāta Civillietu departamenta kādā lietā paustā tēze: Lai atzìtu, ka pastāv likumiska prezumpcija, šādam civillietā nozìmīga fakta esības pieñèmumam ir jābūt tieši noteiktam likumā. ${ }^{7}$ Arī prof. K. Čakste savulaik norādīja, ka vainas prezumpcija pastāv tikai likumā noteiktajos gadījumos. ${ }^{8}$ Tomēr, neraugoties uz to, ka Latvijas tiesību literatūrā atrodams viedoklis, ka pēc vispārējā principa

4 Civillikums: LV likums. Pieṇemts 28.01.1937. Publicēts 20.02.1937. Valdības Vēstnesis, Nr. 41.

5 Ose D. Pierādīšanas process un tā izṇēmumi civilprocesā. Jurista Vārds, 15.12.2015., Nr. 49 (901).

6 Torgāns K. Saistību tiesības. Otrais papild. izd. Rīga: Tiesu namu aǵentūra, 2018, 162. lpp.; agrāk šajā ziṇā prof. K. Torgāns norādīja: Civillikumā nav norādes par šādu prezumpciju. Taču jāatzīst, ka pēc ilgstošiem un nesekmīgiem mēginājumiem nodefinèt vainu citas iespējas arī nebija. Sk.: Torgāns K. Vainas vai attaisnojumu meklējumi civiltiesībās. Jurista Vārds, 31.05.2005., Nr. 20 (375).

7 Latvijas Republikas Augstākās tiesas Senāta Civillietu departamenta 09.12.2019. spriedums lietā Nr. SKC$318 / 2019$.

8 Sal.: Čakste K. Civiltiesības. Lekcijas. Raksti. Rīga: Zvaigzne ABC, 2011, 197. lpp. 
tiesību aizskārēja vaina ir jāpierāda cietušajam, ${ }^{9}$ mūsdienu Latvijas tiesu praksē atrodami gadījumi, kuros šì vispārējā prezumpcija tiek piemērota, tiesām atsaucoties uz minēto CL 1644. panta pirmo daḷu. Tā, piemēram, kādā lietā Vidzemes apgabaltiesas Civillietu tiesas kolēgijas secināja: Tiesas kolégija piekrìt pirmās instances tiesas secinājumam, ka konkrētais tiesību aizskārums izdarīts bez launa nolüka, tātad sāk darboties prezumpcija, ka aizskārējs pielaidis neuzmanību [..] vaina pierādāma, izejot no vainas prezumpcijas, jeb persona atzīstama par vainojamu, ja tā nepierāda savu nevainojamību. ${ }^{10}$

Prof. J. Kārkliṇš norādīja, ka šī viedokḷa par vispārējo vainas prezumpciju civiltiesībās sakne meklējama padomju laiku civiltiesībās, kur šāda prezumpcija tika paredzēta Latvijas PSR Civilkodeksa 229. panta pirmajā daḷā (līgumtiesību kontekstā) un 465. panta otrajā daḷā (deliktu tiesību kontekstā). ${ }^{11}$ Attiecīgi Latvijas PSR Civilkodeksa 229. panta pirmā daḷa noteica: Persona, kas nav izpildījusi saistību vai izpildījusi nepienācīgà veidā, ir mantiski atbildīga tikai tad, ja vinga ir vainīga (nolūks vai neuzmanība), iznemot likumā vai lìgumā paredzētos gadījumus. Vainas neesamība ir jāpierāda personai, kas saistību pārkāpusi. ${ }^{12}$ Kā norādīts šì panta komentārā, personas vaina ir viens no obligātajiem nosacījumiem, kas nepieciešams, lai rastos pienākums atlīdzināt zaudējumus (224. p.). [..] 229. p. vadās no parādnieka vainas prezumpcijas, kas nozīmē, ka civiltiesiskajā atbildībā pretēji kriminālatbildībai prezumē parādnieka vainu, ja parādnieks nav saistību izpildījis. ${ }^{13}$ Savukārt 465. panta otrā daḷa noteica: Kaitējuma nodarītājs atbrīvojas no tā atlīdzināšanas, ja pierāda, ka kaitējums nav nodarìts vin̨a vainas dēḷ. ${ }^{14}{ }^{S} \overline{1}$ panta komentārā norādìts: Kaitējuma nodarītāja vaina arī ir kaitējuma atlìdzināšanas pienākuma priekšnoteikums. [..] Kaitējuma nodarītāja vaina tiek prezumèta. Lai atbrīvotos no kaitējuma atlīdzināšanas, kaitējuma nodarītājam jāpierāda, ka kaitējums nav nodarìts viña vainas dēḷ. ${ }^{15}$ Kā tālāk norādīja prof. J. Kārkliṇš, pēc CL spēka atjaunošanas citi tiesību zinātnieki šo Latvijas PSR Civilkodeksā nostiprināto pozīciju ir nekritiski pārṇēmuši, lai arī iepriekš piesauktajām Latvijas PSR Civilkodeksa normām līdzīgas normas CL nav iestrādātas. ${ }^{16}$ Līdz ar to, lai izprastu CL 1644. panta pirmās daḷas ideju, ir "jārok dziḷāk”, lūkojoties vēsturiskajā regulējumā.

9 Torgāns K., Kārkliņš J. Civiltiesiskās atbildības modẹ̦i pēc vainojamības pazīmes. Jurista Vārds, 08.09.2015., Nr. 35 (887); Ose D. 2015.

10 Sk.: Vidzemes apgabaltiesas Civillietu tiesas kolēǵijas 18.05.2018. spriedums civillietā Nr. C39119515 (stājies likumīgā spēkā). Autora ieskatā, šeit apelācijas instances tiesa varēja minēto strīdu atrisināt uz stingrās atbildības pamatiem, pamatojoties uz konkrētā sadarbības līguma raksturu, kas noslēgts starp cietušā bērna likumisko pārstāvi (vecāku) un pirmsskolas izglīīibas iestādi - tas paredzēja tostarp iestādes pienākumu nodrošināt bērna drošību. Neraugoties uz to, konkrētajā gadījumā notika nelaimes gadījums cietušais bērns, atrodoties uz sporta līdztekām un izpildot skolotājas norādījumu nokāpt no līdztekām, guva miesas bojājumus - tika daḷēji izsisti priekšējie divi kaula zobi.

11 Kārkliņš J. Idea of Strict Liability in Private Law. Grām.: LU žurnāls “Juridiskā Zinātne”, 10. sēj. Rīga: Latvijas Universitāte, 2017, 182. lpp.

12 Autoru kolektīvs P. Stučkas Latvijas Valsts universitātes profesora, juridisko zinātṇu doktora J. Vēbera vispārīgā redakcijā. Latvijas PSR Civilkodeksa komentāri. Rīga: Liesma, 1979, 305. lpp.

13 Turpat, 306.-307. lpp.

14 Turpat, 595. lpp.

15 Turpat, 597. lpp.

16 Kārkliņš J. 2017, 182. lpp. 


\section{Pierādīšanas nastas sadalījums Baltijas vietējo civillikumu kopojumā}

Aplūkojot CL 1644. panta priekšteci - Baltijas vietējo civillikumu kopojuma (turpmāk - BVCK) 3294. pantu -, redzams, ka attieciggais BVCK pants saturēja šādu normu: Ikviena nelikumīga darbība, kas izdarìta bez ḷauna nolūka (3290. p.) atzīstama, ciktāl to var pieskaitìt tās izdarîtājam par vainu, tikai par neuzmanību (culpa), neizšķirot, vai tā notikusi aiz draiskulïbas vai pārgalvības, bez ḷauna nolūka, vai aiz vieglprātības, paviršības, slinkuma vai nepieskaitāmas nezināšanas. ${ }^{17}$ Tiktāl varētu arī apgalvot, ka CL 1644. panta pirmā dal̦a pirmšksietami ir vienkārši neveiksmīgi formulēta, jo vēsturiskās normas tekstā šādas prezumpcijas ielasišana ir pat sarežgiitāks uzdevums. Taču šāds apgalvojums varētu būt krietni pārsteidzīgs. Bez BVCK 3294. panta nodạ̦ā "Neatļauta darbība vispār un vainas pakāpes" vēl bija atrodamas šādas divas normas: 1) BVCK 3293. pants: Kas otru apsūdz par ḷaunprātību, tam tā jāpierāda ${ }^{18}$ 2) BVCK 3304. pants: Pierādījumi par to, ka tiesību aizskārums vispār izdarìts, jāsniedz tam, kas kaitējumu cietis; bet pierādīt, ka aizskärums nav pieskaitāms par vainu, piekrït atbildētājam [autora izcēlums]. ${ }^{19}$ Pierādìt, ka aizskārums nav pieskaitāms par vainu, varēja ar t. s. "ekskulpācijas pierādījumiem". ${ }^{20}$ Abas šìs normas nav pārñemtas CL. Kā redzams, BVCK pierādīšanas pienākuma kontekstā saturēja daudz skaidrāku regulējumu, škietami nosakot vispārēju vainas prezumpciju, kas darbojās kā deliktu tiesībās, tā arī līgumtiesībās.

Tomēr, neraugoties uz šo šķietami nepārprotamo vispārējo vainas prezumpciju BVCK, starpkaru perioda Latvijas Senāta Civilā kasācijas departamenta prakse šajā aspektā rada jautājumus par patieso šīs normas tvērumu. Tā, piemēram, BVCK 3304. panta kontekstā Senāta Civilais kasācijas departaments izteica šādu tēzi: Vaina nav prezumējama, bet tā jāpierāda tam, kas uz to atsaucas. [..] [autora izcēlums]. ${ }^{21}$ Līdzịgi kādā citā lietā Senāta Civilais kasācijas departaments norādīja, ka [..] prasîtājs šai lietā dibina savu prasību, lìdz ar to gan uznẹemoties pierädìt taisni atbildètājas vainu (L. c. l. 3444. p. [CL 1779. panta priekštecis - autora piebilde]), turpretim, ja prasība būtu pamatota ar Dzelzc. lik., tad

17 Baltijas vietējo civillikumu kopojums latviešu valodā: Vietējo likumu kopojuma III daḷa. Neoficiāls izdevums Tieslietu ministrijas sevišḳas komisijas sagatavojumā. Rīga: Valters un Rapa, 1928, 379. lpp.

18 Turpat.

19 Turpat, 380. lpp.

20 Sk.: Latvijas Senāta Civilā kasācijas departamenta 09.11.1922. spriedums Ramiṇa prasỉbā pret Dubultu fabrikas akciju sabiedrïbu. Grām.: Izvilkumi no Latvijas Senata Civilā kasācijas departamenta spriedumiem. I. turpinājums līdz 1926. g. julijam un pirmā izlaiduma papildinājums ar alfabētisko rādītāju abām daḷām. Sastādijuš̌i: Latvijas Tiesu palatas loceklis F. Konradi un Rīgas apgabaltiesas loceklis A. Walter. [B. v.]: autoru izdevums, 1926, 15.-16. lpp.; Latvijas Senāta Civilā kasācijas departamenta 27.09.1934. spriedums Dauces prasībā pret Pḷavnieku. Grām.: (XI) Izvilkumi no Latvijas Senāta Civīlā kasācijas departamenta spriedumiem. X turpinājums ar alfabētisko rāditāju, rādìtāju pievestiem spriedumiem un likumu rāditāju. Sastādijuš̌i: senātors F. Konradi un Rīgas apgabaltiesas loceklis A. Walter. [B. v.]: izdevniecība "Grāmatrūpnieks", 1934, 210.-211. lpp.; Latvijas Senāta Civilā kasācijas departamenta Apvienotās sapulces 29.11.1937. spriedums. Grām.: Izvilkumi no Latvijas Senāta Civilā kasācijas departamenta spriedumiem. Sastādijuši: senātors F. Konradi un Tiesu palātas loceklis A. Valters. Tieslietu Ministrijas Vēstneša pielikums. [B. v.]: Tieslietu ministrijas izdevums, 1938, 77.-80. lpp.

${ }^{21}$ Latvijas Senāta Civilā kasācijas departamenta kopsēdes 26.04.1939. spriedums Streipas prasībā pret biedrību "Muitas artelis". Grām.: XV Izvilkumi no Latvijas Senāta Civilā kasācijas departamenta spriedumiem. Sastādijušsi: senators F. Konradi, Tiesu palātas loceklis A. Valters. Tieslietu ministrijas Vēstneša pielikums. Rīga: Tieslietu ministrijas izdevums, 1939, 270.-271. lpp. 
dzelzceliem savukārt būtu - ekskulpācijas veidā - jāpierāda tādu apstākḷu esamība, kas atsvabinātu vinu no atbildības [..] [autora izcēlums]. ${ }^{22}$ Šo tēzi Senāta Civilais kasācijas departaments uzturēja arī pēc tam, kad tālaika Dzelzceḷa likumā tika veikti grozījumi attiecībā uz pierādīšanas pienākuma jautājumu: Tātad [Dzelzcel̦a likuma - autora piebilde] 97. p. savā tagadèjā redakcijā vairs neuzliek dzelzceḷam ekskulpācijas pierādī̌sanas pienākumu, bet šai ziņā neatkäpjas no vispärējä CL pieņemtā principa, ka tam, kas prasa atlìdzību par zaudējumiem, jäpierāda atbildètāja vaina (CL 3284., 3440. p.) [autora izcēlums]. Tāpēc arī konkrētajā gadījumā prasītājai bija jāpierāda dzelzceḷa vaina ar prasītāja mantu notikušā nelaimes gadijumā. $^{23}$

Attiecīgi, [..] ciktāl prasîtājs zaudējumu atlīdzinājuma pienākumu pamato ar CL. 3444. p. noteikumiem, viņš taisni nevar apiet vainas jautājumu [autora izcēlums]. ${ }^{24}$ Vēl uzskatāmāk šì doma pausta kādā citā Senāta Civilā kasācijas departamenta izspriestā lietā: Ekskulpäcijas pierādījumu var uzlikt tikai vainīgam; šajā ziņā CL 3304. p. tieši nosaka, ka, ja ir pierādīts tiesību aizskārums, kas nav izdarīts l̦aunprātīgi, tad pierādìt, ka tas noticis bez atbildètāja vainas vai neuzmanības, piekrīt pēdējam [autora izcēlums]. Tātad pašam prasītājam vispirms bütu jāpierāda pats tiesību "aizskārums", t. i., atbildètāja pati par sevi neatl̦autā darbība (CL 3284. p. beigās) [autora izcēlums]. Tātad, arī konkrētajā lietā prasītājai būtu bijis visupirms jāpierāda, ka atbildētājs, notārs J., apliecinot pilnvaras parakstītāja personību uz pases pamata, nodarījis neatḷautu darbību, kas bütu pieskaitäma viņam par vainu [autora izcēlums]. ${ }^{25}$ Vēlreiz izlasot BVCK 3304. pantu un iepriekš citētās Senāta Civilā kasācijas departamenta atziṇas, nebūtu pārspīlēti teikt, ka rodas neizpratne - BVCK 3304. pants, no vienas puses, paredzēja, ka pienākums "pierādīt, ka aizskārums nav pieskaitāms par vainu, piekrīt atbildētājam”, savukārt Senāta Civilais kasācijas departaments, no otras puses, vairākkārt uzsvēris, ka "atbildētāja vaina nav prezumējama"; "prasītājam jāpierāda atbildētāja vaina”; "ekskulpācijas pierādījumu var uzlikt tikai vainīgam”. Uzreiz jāteic, ka risinājums, lai kliedētu šo neizpratni, nav acīmredzams. Šeit jāṇem vērā divi aspekti.

Pirmais no tiem ir saistāms ar terminologiskām niansēm CL un BVCK. CL 1635. pantam atbilstošais BVCK 3284. pants ${ }^{26}$ vārdkopas "ciktāl viṇu par šo darbību var vainot" vietā saturēja vārdkopu "ciktāl šo darbību var pieskaitīt

${ }^{22}$ Latvijas Senāta Civilā kasācijas departamenta 26.10.1933. spriedums Tenesa prasībā pret Dzelzceḷa virsvaldi. Grām.: X Izvilkumi no Latvijas Senāta Civīlā kasācijas departamenta spriedumiem. VIII turpinājums ar alfabētisko rādītāju, rādītāju pievestiem spriedumiem un likumu rādītāju. Sastādījuši: senātors F. Konradi un Rīgas apgabaltiesas loceklis A. Walter. [B. v.]: izdevniecība "Jūrists", 1933, 81. lpp.

${ }^{23}$ Latvijas Senāta Civilā kasācijas departamenta 27.01.1937. spriedums AS "Livonija” prasībā pret Dzelzceḷa virsvaldi. Grām.: (XIII) Izvilkumi no Latvijas Senāta Civīā kasācijas departamenta spriedumiem. Sastādijuši: senātors F. Konradi un Rīgas apgabaltiesas loceklis A. Valters. Tieslietu Ministrijas Vēstneša pielikums. [B. v.]: Tieslietu ministrijas izdevums, 1936/1937, 342.-343. lpp.

${ }^{24}$ Latvijas Senāta Civilā kasācijas departamenta 25.11./16.12.1936. spriedums Hausmaṇa prasībā pret Latvijas valsti, Finanču min. personā. Grām.: (XIII) Izvilkumi no Latvijas Senāta Civīlā kasācijas departamenta spriedumiem. Sastādijjuši: senātors F. Konradi un Rīgas apgabaltiesas loceklis A. Valters. Tieslietu Ministrijas Vēstneša pielikums. [B. v.]: Tieslietu ministrijas izdevums, 1936/1937, 479. lpp.

25 Latvijas Senāta Civilā kasācijas departamenta 28.09.1937. spriedums Rīgas hipotēku biedrības prasībā pret Ansonu u. c. Grām.: (XIII) Izvilkumi no Latvijas Senāta Civīlā kasācijas departamenta spriedumiem. Sastādījuši: senātors F. Konradi un Rīgas apgabaltiesas loceklis A. Valters. Tieslietu Ministrijas Vēstneša pielikums. [B. v.]: Tieslietu ministrijas izdevums, 1936/1937, 747.-748. lpp.

26 Baltijas vietējo civillikumu kopojums latviešu valodā: Vietējo likumu kopojuma III daḷa. Neoficiāls izdevums Tieslietu ministrijas sevišksas komisijas sagatavojumā. Rìga: Valters un Rapa, 1928, 378. lpp. 
viṇam par vainu”. Šāda terminologiska atšķirība novērojama arī citās normās: CL 1637. pantam atbilstošais BVCK 3286. pants $^{27}$ vārdkopas "nav vainojami" vietā saturēja vārdkopu "nepieskaita par vainu”. Līdzīgas izmaiṇas novērojamas arī CL 1638. un 1644. pantam atbilstošajā BVCK 3287. ${ }^{28}$ un 3294. pantā. ${ }^{29}$ Turklāt CL 1640. pantā regulētās vainas pakāpes atbilstošajā BVCK 3289. pantā ${ }^{30}$ bija nosauktas par pieskaitāmības pakāpēm. No šì pantu salīdzinājuma izriet būtisks secinājums - CL šobrīd lietoto vainas un vainojamības jēdzienu BVCK faktiski apvienoja zem vienota jēdziena - vaina, kura tiesību aizskārējam bija “jāpieskaita", lai piemērotu civiltiesisko atbildību. Ar jēdzienu "vaina" BVCK aptvēra ne tikai vainas pakāpes, bet arī izṇēmumus no atbildības piemērošanas, piemēram, tiesību aizskārumus, ko nodarījuši bērni līdz septiņu gadu vecumam vai personas ar garīga rakstura vai citiem veselības traucējumiem (CL 1637. panta pirmā daḷa).

Otrs aspekts saistāms ar apsvērumu, ka starpkaru perioda Latvijas civiltiesībās vainas un atbildības izslēdzoša apstākḷ - nejauša šḳēršla (nejaušības) - jēdzieni tika savstarpēji pretnostatīti, ievērojot, ka nejaušiba bija tur, kur notikumu krietns un rūpīgs saimnieks nevarēja nedz paredzēt, nedz novērst, - tur attiecīgi nav arī vainas. Kā norādījis tiesību zinātnieks N. Vīnzarājs, abi kvalificētie gadījumi (nejaušs notikums un nepārvarama vara) izslēdz parādnieka vainu. ${ }^{31}$ Vienlaikus nejaušības jēdzienam tika izmantoti līdzīgi kritēriji, kas tika analizēti vainas (neuzmanības) ietvaros - kaitējuma paredzamība un novēršamība. ${ }^{32}$ Šajā ziṇā jāatzīmē prof. V. Sinaiska izteikts novērojums, ka BVCK parastā gadījuma (vainas) un kvalificētā gadījuma (nejaušības) izpratnes tika sajauktas kopā. ${ }^{33}$

Ko no šì visa var izsecināt? Autora ieskatā, tas liek pamatoti domāt, ka BVCK lietotais vainas jēdziens bija ārkārtīgi ietilpīgs - tas aptvēra ne tikai klasisko (šaurāko) vainas izpratni, proti, ka atbildības piemērošanai bija jākonstatē tiesību aizskārēja neuzmanība vai nolūks, bet tas aptvēra arī atbildību izslēdzošus apstākḷus, tostarp nejaušu šḳērsli (nejaušu notikumu un nepārvaramu varu), sev piederošas tiesības izlietošanu u. tml. (tātad arī vainas plašāko izpratni). Saskaṇā ar šādu vainas jēdziena izpratni BVCK, var izskaidrot to, ka patiesībā BVCK 3304. pants un šīs normas sakarā atrodamā Senāta Civilā kasācijas departamenta prakse ir savstarpēji saskanīgi un ka attiecīgi nerodas arī nekādas pretrunas.

Un proti, BVCK 3304. pants (Pierādījumi par to, ka tiesību aizskārums vispār izdarīts, jāsniedz tam, kas kaitējumu cietis; bet pierādīt, ka aizskārums nav pieskaitāms par vainu, piekrīt atbildētājam) ir iztulkojams šādi: a) cietušajam ir jāpierāda "tiesību aizskārums" (jeb, kā norādījis Senāta Civilais kasācijas departaments, neatḷauta darbība) - tiesību aizskārēja vaina (neuzmanība vai nolūks) (tātad vainas

${ }^{27}$ Baltijas vietējo civillikumu kopojums latviešu valodā: Vietējo likumu kopojuma III daḷa. Neoficiāls izdevums Tieslietu ministrijas sevišķas komisijas sagatavojumā. Rīga: Valters un Rapa, 1928, 378. lpp.

28 Turpat.

29 Turpat, 379. lpp.

30 Turpat, 378. lpp.

31 Vīnzarājs N. Gadījuma loma savstarpējos (sinallagmatiskos) līgumos. Tieslietu Ministrijas Vēstnesis, 1932, Nr. 7/8, 243.-256. lpp.

32 Буковский В. (сост.) Сводь гражданскихъ узаконений губерний Прибалтийскихъ (съ продолжениемъ 1912-1914 г. и съ разъяснениями) въ 2 томахъ. Т. II., содержащий Право требований. Рига: Г. Гемпель и Ко, 1914, с. 1299, 1390-1391; Čakste K. Nejaušíba un nepārvarama vara Latvijas Civillikumos. Jurists, 1937, Nr. 71/72, 12.-16. lpp.

33 Синайский. В. И. Основы гражданского права. В связи с частью III Свода указонений, действующих в Латвии и Эстонии. Выпуск II. Рига: издание акц. о-ва Вальтерс и Рапа, 1926, с. 284. 
šaurākajā izpratnē esība), kuras rezultātā nodarīts atlīdzināms kaitējums; kad tas izdarīts, b) tiesību aizskārējam jāpierāda, ka "aizskārums nav tomēr pieskaitāms par vainu”, piemēram, ka kaitējums radies sakarā ar nejaušu notikumu (tātad vainas plašākajā izpratnē neesību). Arī prof. I. Tjutrjumovs zaudējumu atlīdzināšanas pienākuma kontekstā ir norādījis, ka tieši prasītājam (cietušajam) ir jāpierāda, ka atbildētāja neatḷautā rīcība notikusi l̦auna nolūka vai neuzmanības formā, kur savukārt atbildētājam ir iespēja pierādīt, ka konkrētās sekas tas nevarēja novērst, ${ }^{34}$ piemēram, sakarā ar nejaušu šḳērsli (nejaušību). Šāda izpratne izskaidro to, kāpēc Senāta Civilais kasācijas departaments vairākkārt uzsvēra, ka tiesību aizskārēja vaina (šaurākajā izpratnē) nav prezumējama - tā cietušajam ir jāpierāda, savukārt tiesību aizskārējs varēja pierādīt, ka nav konstatējama vina vaina (plašākajā izpratnē) sakarā, piemēram, ar nejaušu šķērsli. Minētie atbildību izslēdzošie apstākḷi arī ir šie "ekskulpācijas pierādījumi”, uz kuriem norādījis Senāta Civilais kasācijas departaments: [..] atbildētājam, kā vainīgai pusei, ekskulpācijas veidā jāpierāda, ka tiesību aizskārums noticis bez viņa vainas, t. i., nejauši (3443. p.) [autora izcēlums]. ${ }^{35}$

Šie apsvērumi kopumā arī raksturo t. s. "vainas principu”, kas tika plaši atzīts starpkaru perioda tiesību doktrīnā un tiesu praksēe, pretnostatot to t. s. "nodarījuma principam": [..] necenšoties uzklausīt attaisnojumu [piemēram, nejaušu šķērsli - autora piebilde] vai meklèt vainas esamību vai neesamību [neuzmanību vai l̦aunu nolūku - autora piebilde] [autora izcēlums]. [..] Tad pietika tikai tīri àrēja sakarība - zaudējumu nodarīšanas fakts [..] vainas princips neapmierinās ar tādu $\bar{a}$ rēju sakarību. ${ }^{36}$

Rezumējot minēto, izdarāms secinājums, ka CL 1644. panta pirmās daḷas priekštecis - BVCK 3294. pants (un citas saistītās normas) - nesaturēja vispārēju vainas (neuzmanības) prezumpciju, lai gan BVCK 3304. pants pirmšķietami vedināja domāt, ka BVCK šādu prezumpciju saturēja. N̦emot vērā, ka BVCK 3304. panta analogs CL nav atrodams, var secināt, ka CL sastādītāji vēlējušies vēl skaidrāk norādìt, ka šāda vispārēja prezumpcija CL netiek paredzēta (lai gan, kā redzams, Senāta Civilais kasācijas departaments neapjuka, piemērojot BVCK 3304. pantu). Katrā ziṇā CL palikusī 1644. panta pirmā daḷa joprojām ir maldinoša un prasa precizējumus, lai norma būtu viennozīmīgāka. Lìdz ar to turpmāk autors apskata, kādā virzienā CL 1644. panta pirmā daḷa varētu bùt precizējama, balstoties uz vispārīgajiem pierādīšanas principiem un ìpatnībām, piemērojot civiltiesisko atbildību deliktu tiesībās un līgumtiesībās.

\section{Pierādīšanas nastas sadalījuma īpatnības deliktu tiesībās un līgumtiesỉbās}

Sākotnēji nepieciešams iezīmēt deliktu tiesību un līgumtiesību būtisko atšķirību - nodibinot līgumiskās attiecības, puses ir brīvas nodrošināties pret

\footnotetext{
34 Тютрюмов И. Гражданское право. Второе, исправленное и значительно дополненное издание. Тарту: Типография Г. Лаакманъ, 1927, с. 139.

35 Latvijas Senāta Civilā kasācijas departamenta 22.11.1933. spriedums Amerika prasībā pret Eriṇu. Grām.: X Izvilkumi no Latvijas Senāta Civīā kasācijas departamenta spriedumiem. VIII turpinājums ar alfabētisko rādītāju, rādītāju pievestiem spriedumiem un likumu rādītāju. Sastādījuši: senātors F. Konradi un Rīgas apgabaltiesas loceklis A. Walter. [B. v.]: izdevnieciba "Jūrists", 1933, 59. lpp.

${ }^{36}$ Sk.: Čakste K. 2011, 191.-193. lpp.
} 
neparastiem riskiem. Taču šādas iespējas nav delikta gadījumā, ${ }^{37}$ šeit kaitējums tiek nodarīts negaidīti bez iepriekšējas pušu vienošanās, un parasti cietušajiem nav bijusi iespēja veikt zināmus priekšdarbus, lai aizsargātu savas intereses kaitējuma nodarīšanas gadījumā. ${ }^{38}$ No šìs aksiomas Šveices tiesību literatūrā tiek atvasināts princips, ka delikta gadījumā puses ir vienlīdzīgas, tās vienlīdz labi zina lietas apstākḷus. Savukārt līgumtiesībās līguma pārkāpuma apstākḷi atrodas parādnieka sfērā, nevis kreditora, tādējādi pamatojot vainas prezumpcijas nepieciešamību līgumtiesībās. ${ }^{39}$ Lìdzīga pieeja pastāv arī Vācijā un Austrijā. ${ }^{40}$ Pakavējoties pie šì principa, jāatzīmē, ka, autora ieskatā, to nevarētu absolutizēt. Tā, piemēram, būvniecībā šie apstākḷi mēdz atrasties vienlaikus abu līdzēju (pasūtītāja un būvdarbu veicēja) sfērā, kas pamato no CL 1. panta izrietošā abpusējas sadarbošanās pienākuma esību. ${ }^{41}$ Nereti būvniecībā līguma pārkāpumu izraisa arī kreditora (pasūtītāja) bezdarbība, piemēram, būvlaukuma neierādīšana, kas dod būvdarbu veicējam tiesības izteikt līguma neizpildǐšanas ierunu.

Jebkurā gadijumā jāteic, ka kritērijs - kuras personas sfērā atrodas strīdīgie apstākḷi - ir atzīts princips, kuru ievēro, nosakot pierādī̌̌anas nastas sadali. Tā, piemēram, idejiski šādu apsvērumu dēl vainas prezumpcija ir noteikta arī kapitālsabiedrību valdes locekḷ atbildības regulējumā (Komerclikuma ${ }^{42}$ 169. panta trešā daḷa), ievērojot, ka tieši valdes loceklis vislabāk spēj pamatot, kāpēc konkrētajos apstākḷos tika, piemēram, noslēgts zaudējumus nesošais darījums, tam uzrādot attiecīgus pierādījumus, kas apstiprina prasītās rūpības ievērošanu (piemēram, uzrādot pirms darījuma slēgšanas pasūtīto eksperta atzinumu, kas satur slēdzienu, ka sabiedrības manta pārdota par tirgus cenu). Līdzīgu apsvērumu dēl vainas prezumpcija noteikta, piemēram, kustoṇa vai dzìvnieka turētājam, jo tikai tas spēj pierādīt, ka rīkojies bez neuzmanības, t. i., [..] ir spēris visus pēc apstākḷiem nepieciešamos drošības soḷu, vai ka zaudējums būtu noticis, neraugoties uz visiem drošỉbas soḷiem (CL 2363. pants).

Anglosakšu tiesību literatūrā pieeja, ka pierādīšanas nasta jāuzliek tai pusei, kurai ir labāka piekḷuve nepieciešamajai informācijai, tikusi kritizēta. Proti, tiek uzskatīts, ka šì pieeja labi darbojas līgumtiesībās, bet ne deliktu tiesībās, proti, atbilstoši šai loǵikai ir pamatoti uzlikt pierādī̌̌anas nastu līgumpārkāpējam, taču delikta gadījumā ne jau cietušais labāk zinās par tiesību aizskārējam pieejamajiem piesardzības pasākumiem (to izdevumiem), bet gan pats tiesību aizskārējs. ${ }^{43}$ Neraugoties uz šo kritiku, deliktu tiesībās dominē princips, ka tiesību aizskārēja vaina pēc vispārējā noteikuma jāpierāda cietušajam, ja vien tiesību normās nav noteikta vainas prezumpcija (CL 2363. pants) vai stingrās atbildības modelis (CL 2347. panta otrā daḷa). Jau romiešu tiesībās tika atzìta pieeja, ka deliktu tiesībās

${ }^{37}$ Major W. T., Taylor Ch. Law of Contract. $9^{\text {th }}$ ed. London: M \& E Pitman Publishing, 1996, p. 279.

38 Peel E. The Law of Contract. Thirteen edition. London: Sweet \& Maxwell, Thomson Reuters, 2011, p. 1055.

39 Sk.: Schwenzer I. Schweizerliches Obligationenrecht. Algemeiner Teil. 7. Aufl. Bern: Stämpfli Verlag AG, 2016, S. 155.

40 Winiger B., Karner E., Oliphant K. (eds.). Digest of European Tort Law. Vol. 3: Essential Cases on Misconduct. Berlin/Boston: Walter de Gruyter GmbH, 2018, p. 27.

41 Daži jautājumi par uzṇēmuma līguma izpratni (J. Kārkliņa viedoklis). Jurista Vārds, 10.09.2019., Nr. 36 (1094).

42 Komerclikums: LV likums. Pieṇemts 13.04.2000. Publicēts 04.05.2000., Latvijas Vēstnesis, 01.06.2000., Nr. 158/160; Latvijas Republikas Saeimas un Ministru Kabineta Ziṇotājs, Nr. 11.

${ }^{43}$ Posner E. A. Fault in Contract Law. Michigan Law Review, Vol. 107, No. 8. Symposium: Fault in American Contract Law, 2009. 
vaina pēc vispārējā principa bija jāpierāda cietušajam. ${ }^{44}$ Tā arī Kopējā modeḷa projekta $^{45}$ (Draft of Common Frame of Reference) komentāros norādìts, ka delikta gadījumā cietušajam būtu jānorāda un, ja nepieciešams, arī jāpierāda visi atbildības priekšnoteikumi. ${ }^{46}$ Attiecīgi mūsdienās cietušajam vaina ir jāpierāda, piemēram, Austrijā, Šveicē, Griek̦ijā, Francijā, Beḷgijā, Spānijā, Portugālē, Anglijā, Dānijā, Somijā, Polijā, Čehijā. ${ }^{47}$ Savukārt vainas prezumpcija deliktu tiesībās pastāv, piemēram, Lietuvā, Slovākijā, Horvātijā. ${ }^{48}$

Deliktu tiesību kontekstā mūsdienu Augstākās tiesas Senāta Civillietu departamenta praksē ir atrodama tā pati pieeja, kas pastāvēja iepriekš aprakstīto BVCK normu sakarā, proti, ka tiesību aizskārēja vaina (neuzmanība vai nolūks) (tātad šaurākā vainas izpratne) ir jāpierāda cietušajam. Tā, piemēram, kādā lietā cietušais (kāda hokeja kluba bijušais audzēknis) cēla prasību pret hokeja treneri, hokeja klubu un Latvijas valsti par solidāru morālā kaitējuma atlīdzināšanu par veselībai nodarīto kaitējumu un sakropḷojumu, prasītājam uzskatot, ka viņam tika piemērota veselības stāvoklim neatbilstoša treniņu programma un tehnika, kā arī tikuši piel̦auti pārkāpumi ārstniecības procesā, un rezultātā prasītājam sirds vairs nedarbojās bez EKS defibrilatora. Augstākās tiesas Senāta Civillietu departaments norādīja: [..] lai noskaidrotu lietas apstākḷus, kuri ietilpst pierādīšanas priekšmetā, tiesai bija jān,em vērā, ka vispārīgi prasījumos par zaudējumu atlīdzinājumu prasītājam jāpierāda: 1) tiesību aizskārums, ar ko vinam nodarìti zaudējumi (sk. Civillikuma 1635. pantu); 2) ar šo tiesību aizskārumu nodarìto zaudējumu apmērs (sk. Civillikuma 1779. pantu) [autora izcēlums]. Savukārt atbildētājam jāpierāda: 1) ka viņš nav vainojams zaudējumu nodarīšanā (sk. Civillikuma 1636. un 1638. pantu); 2) vai ka prasītājs pats vainīgs pie zaudējumu nodarīšanas, jo nav ievērojis pienācīgu rūpību (sk. Civillikuma 1646. un 1776. pantu); 3) vai ka prasītājs pats rīkojies l̦aunā nolūkā (sk. Civillikuma 1642. pantu) [autora izcēlums]. ${ }^{49}$ Šāds pierādīšanas standarts tika piemērots arī kādā citā deliktu tiesību strīdā. ${ }^{50}$

Savā ziṇā ir pārsteidzoši, ka, tā kā CL nav tādas normas, kādu saturēja BVCK (3304. pants: Pierādījumi par to, ka tiesību aizskārums vispār izdarìts, jāsniedz tam, kas kaitējumu cietis; bet pierādīt, ka aizskārums nav pieskaitāms par vainu, piekrìt atbildētājam), mūsdienu Augstākās tiesas Senāta Civillietu departaments savā praksē ir nonācis pie faktiski BVCK 3304. panta risinājuma. Citētajā pierādī̌sanas nastas sadalījumā sevišķa uzmanība pievēršama tam, ka attiecībā uz prasītāja pienākumā ietilpstošo pierādīšanas priekšmetu ietverta atsauce uz CL 1635. pantu, savukārt attiecībā uz atbildētāja pienākumā ietilpstošo pierādīšanas priekšmetu - uz CL 1636. un 1638. pantu, kas uzskaita atbildību izslēdzošus apstākḷus - sev piederošas tiesības izlietošanu, darbošanos pēc aizskartās personas

\footnotetext{
${ }^{44}$ Winiger B., Karner E., Oliphant K. 2018, p. 20.

45 Kopējā model̦a projekts (Draft of Common Frame of Reference). Pieejams: https://www.law.kuleuven.be/ personal/mstorme/2009_02_DCFR_OutlineEdition.pdf [aplūkots 18.02.2021.].

46 von Bar C., Clive E. (eds.). Principles, Definitions and Model Rules of European Private Law. Prepared by the Study Group on a European Civil Code and the Research Group on EC Private Law (Acquis Group). New York: Oxford University Press, 2010, p. 3407.

47 Winiger B., Karner E., Oliphant K. 2018, pp. 26, 29, 30, 34, 37, 45, 48, 50, 60, 66, 77, 79.

48 Ibid., pp. 67, 73, 82, 87.

${ }^{49}$ Latvijas Republikas Augstākās tiesas Senāta Civillietu departamenta 17.12.2019. spriedums lietā Nr. SKC251/2019, 8.2 punkts.

${ }^{50}$ Latvijas Republikas Augstākās tiesas Senāta Civillietu departamenta 29.08.2019. spriedums lietā Nr. SKC240/2019, 5.1 punkts.
} 
gribas, atḷautu pašaizstāvību, apakšnieka nodarìtu tiesību aizskārumu pēc priekšnieka pavēles. Kā redzams, šeit Augstākās tiesas Senāta Civillietu departaments lieto vainojamības jēdzienu, ko agrāk BVCK (un attiecīgi Senāta Civilais kasācijas departaments) apzīmēja ar vienoto (plašo) vainas jēdzienu.

Tāpat mūsdienu Latvijas Republikas Augstākās tiesas Civillietu departaments deliktu tiesību kontekstā atzinis, ka prasītājam kā cietušajam, cel̦ot prasību uz CL 1635. panta pamata, ir jāpierāda visi civiltiesiskās atbildības

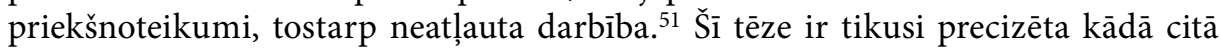
lietā: Lai piepildìtu Civillikuma 1635. panta materiālo sastāvu, prasìtājam tas lìdz saprātīgas ticamības pakāpei jāpierāda, bet tiesas spriedumā jāieklauj attiecīgā motivācija. ${ }^{52}$ Šeit gan jāatzīmē, ka minētais tēzes precizējums tika izteikts lietā, kurā tika skatīts jautājums par saskarsmes tiesībām. Attiecīgi, tā kā cietušajam delikta gadījumā pēc vispārēja noteikuma jāpierāda visi civiltiesiskās atbildības priekšnoteikumi, tad prasītājam kā cietušajam jāpierāda arī atbildētāja kā iespējamā tiesību aizskārēja vaina, piemēram, rupja neuzmanība kā neatḷauta vainas pakāpe. ${ }^{53}$ Kādā lietā Augstākas tiesas Civillietu departaments ìpaši atzīmēja, ka ceḷu satiksmes noteikumu pārkāpuma fakts un ceḷu satiksmes negadījuma izraisīšanas fakts pats par sevi nerada ne vieglas, ne rupjas neuzmanïbas prezumpciju [autora izcēlums]. Ceḷu satiksmes negadïjumu iespējams izraisìt gan ar vieglu, gan rupju neuzmanību, un šo neuzmanības veidu nošḳiršanai nepieciešams noskaidrot zaudējumus izraisījušās personas rīcību konkrētā negadījuma apstākḷos un subsumèt to Civillikuma 1646., 1645. pantu normām. ${ }^{54}$

Pirms pievērsties līgumtiesībām, sākotnēji nepieciešams atzīmēt, ka vainas jautājums līgumtiesībās parasti nav tik problemātisks kā deliktu tiesībās (deliktu tiesībās vaina (tās izpausme - neuzmanība) ir atbildības piemērošanas fundaments). Līgumtiesībās atbildība principā tiek balstīta uz līguma noteikumiem, kas privātautonomijas ietvaros papildus likuma noteikumiem detalizē un konkretizē pušu uzvedības modeli (nosaka prasītās rūpỉbas standartu) (CL 1785. pants). Lìdz ar to līgumattiecībās ir vieglāk identificēt vainu - līdzēja veiktās rīcības neatbilstību prasītās rūpibas standartam, jo atliek norādīt uz kāda līguma noteikuma neizpildi. Pie tam jāatzīmē, ka pastāv arī t. s. "stingrās atbildības grupas" saistības, piemēram, maksāšanas saistības, lietas izgatavošanas saistība, kur parādnieka vainas (neuzmanības) vērtējumam nebūs izšḳirīgas juridiskas nozīmes. Šāda tipa saistībās parādniekam ir pienākums nevis pielikt visas saprātīgās pūles, bet gan garantēt noteiktu rezultātu. Tāpat jāṇem vērā, ka puses privātautonomijas ceḷā bieži vien izmaina likumā noteikto atbildības modeli, tipiski paredzot stingrāku atbildību (piemēram, ietverot garantijas saistības). Plašāk par vainas nozīmi lìgumtiesībās autors aicina skatīt autora rakstu "Vainas elementi līgumiskās atbildības piemērošanā" ${ }^{55}$

${ }^{51}$ Latvijas Republikas Augstākās tiesas Civillietu departamenta 27.06.2018. spriedums lietā Nr. SKC159/2018, 8. punkts.

${ }^{52}$ Latvijas Republikas Augstākās tiesas Senāta Civillietu departamenta 11.02.2020. spriedums lietā Nr. SKC$166 / 2020,7$. punkts.

${ }^{53}$ Latvijas Republikas Augstākās tiesas Senāta Civillietu departamenta 14.03.2007. spriedums lietā Nr. SKC$110 / 2007$

${ }^{54}$ Latvijas Republikas Augstākās tiesas Civillietu departamenta 20.04.2016. spriedums lietā Nr. SKC0105/2016, 12.3 punkts.

55 Sk.: Brants E. Vainas elementi līgumiskās atbildības piemērošanā. Grām.: Starptautisko un Eiropas Savienības tiesību piemērošana nacionālajās tiesās. Latvijas Universitātes 78. starptautiskās zinātniskās konferences rakstu krājums. Rīga: LU Akadēmiskais apgāds, 2020, 270.-286. lpp. 
Attiecīgi līgumtiesību kontekstā, izpētot Latvijas tiesu praksi, jāsecina, ka šeit reizēm novērojama tendence noteikt atbildētāja (līgumpārkāpēja) vainas prezumpciju. Šajā kontekstā jāpiemin šāda starpkaru perioda Senāta Civilā kasācijas departamenta paustā tēze: [..] nomas priekšmeta pasliktināšanās gadījumā iznomātājam jāpierāda š̀ priekšmeta labākā kvalitāte tā nodošanas laikā [tātad jāpierāda zaudējumu apmērs - autora piebilde]; nomniekam šādā gadījumā turpretim jāpierāda, ka pasliktināšana nav pieskaitāma viņam par vainu (L. c. l. 3304. p. [....$^{56}$ Analogískas atziñas izteiktas arī mūsdienu Augstākās tiesas Senāta Civillietu departamenta praksē. Kādā lietā, kurā tika risināts strīds starp advokātu un viņa klientu par sniegto juridisko pakalpojumu apjomu un kvalitāti, Senāta Civillietu departaments atzina, ka pēc vispārēja noteikuma prasībās atlìdzināt zaudējumus, kas radušies sakarā ar saistības neizpildīšanu, prasītājam jāpierāda: pirmkārt, tiesība prasìt izpildī̌̌sanu, t. i., viñam jāpierāda tiesiskas attiecības esība, uz kuras pamata atbildètājam pienākas izpildìt; otrkārt, izpildīšanas termina iestāšanās; treškārt, prasot zaudējumu atlīdzību - zaudējuma apmērs (sk. Civillikuma 1401., 1402., 1785. pantu) [autora izcēlums]. Savukārt atbildètājam pēc analogijas ar Civillikuma 1838. pantu jāpierāda, ${ }^{57}$ ka viņš savu no lïguma izrietošo saistību ir izpildījis, jo viņa pienākums izteicies darbībā (sk. arī Bukovskis V. Civilprocesa mācību grāmata. Rìga: Autora izdevums, 1933, 774. Іpp.) [autora izcēlums]. Respektīvi, ja advokāts veicis konkrētas darbības juridiskās palīdzības sniegšanas ietvarā, tad viņam šo darbību apjoms un kvalitāte arī ir jäpierāda, iesniedzot atbilstošus pierādījumus [autora izcēlums]. ${ }^{58}$ Minētais pierādīšanas standarts tika piemērots arī kādā būvniecības strīdā starp pasūtītāju un būvdarbu veicēju..$^{59}$

Līdzīgu atziṇu Senāta Civillietu departaments izteica kādā citā lietā, norādot: [..] pārvaldnieku no atbildības par dzīvojamās mājas komunikāciju bojājuma rezultātā radìto kaitējumu ir pamats atbrīvot, ja ir ievērota lìgumā un likumā noteiktā kārtība un pārvaldnieks no savas puses ir veicis visas nepieciešamās darbības, bet dzīvokḷu īpašnieki kopsapulcē ir nobalsojuši pret pārvaldnieka ierosinājumu [autora izcēlums]. ${ }^{60}$ Analoǵiski Augstākās tiesas Senāta Civillietu departaments vēl kādā citā lietā secināja: Kā iepriekš jau norādīts, pārvaldnieks bütu atbrīvots no atbildības, ja viņš no savas puses būtu rīkojies ar pienācīgu rüpību savu pielìgto pienäkumu izpildē [autora izcēlums]. ${ }^{61}$

Šeit nedaudz jāpakavējas pie iepriekš apskatītā strīda starp advokātu un viṇa klientu. Šajā ziṇā autora uzmanību piesaistīja Senāta Civillietu departamenta liktā

${ }^{56}$ Latvijas Senāta Civilā kasācijas departamenta 27.09.1934. spriedums Dauce prasībā pret Pḷavnieku. Grām.: (XI) Izvilkumi no Latvijas Senāta Civīlā kasācijas departamenta spriedumiem. X turpinājums ar alfabētisko rādītāju, rādītāju pieviestiem spriedumiem un likumu rādītāju. Sastādỉjuši: senātors F. Konradi un Rīgas apgabaltiesas loceklis A. Walter. [B. v.]: izdevniecība "Grāmatrūpnieks", 1934, 210.-211. lpp.

57 CL 1838. pants: Ka samaksa izdarīta, jāpierāda tam, kas to apgalvo. Pierādìt samaksu var ar visiem atļautiem pierādījuma lìdzekḷiem, bet sevišķi ar rakstisku apliecinājumu jeb kvīti; samaksas sañēmējs nedrīkst atteikties to izdot parādniekam. Kvīti var izrakstīt vai nu uz paša parāda akta, ja tāds ir, vai atseviški.

${ }^{58}$ Latvijas Republikas Augstākās tiesas Senāta Civillietu departamenta 31.10.2019. spriedums lietā Nr. SKC316/2019, 10.1-10.2 punkts.

59 Latvijas Republikas Augstākās tiesas Senāta Civillietu departamenta 05.05.2020. spriedums lietā Nr. SKC59/2020, 10.1 punkts.

60 Sk.: Latvijas Republikas Augstākās tiesas Senāta Civillietu departamenta 16.03.2020. spriedums civillietā Nr. SKC-146/2020, 8.4 punkts.

${ }^{61}$ Latvijas Republikas Augstākās tiesas Senāta Civillietu departamenta 16.10.2019. spriedums lietā Nr. SKC248/2019, 7.2 punkts. 
atsauce uz prof. V. Bukovska atziṇām. Aplūkojot šo avotu, atklājas aina, ka prof. V. Bukovskis ir noteicis faktiski identisku atbildētāja pierādī̌anas standartu kā prasījumam izpildìt līgumu, tā arī prasījumam atlīdzināt līguma neizpildes dēl nodarìtos zaudējumus. Proti, prasot izpildìt ar līgumu uzṇemtās saistības, atbildētājam jāpierāda: 1) ka viņš ir jau izpildījis ar līgumu uzñemtās saistības, 2) vai arī ka pēc darījuma rakstura izpildīšana papriekš izdarāma no prasītāja puses (Civîllik. 3213. un 3531. p.) (pēc analogijas). ${ }^{62}$ Savukārt, prasot atlìdzināt ar saistības neizpildīšanu nodarìtos zaudējumus, atbildētājam jāpierāda, ka viņš ir izpildījis, jo viña pienākums izteicas darbībā (in faciendo) (Civîllik. 3531. p.) (pēc analoğijas). ${ }^{63} \mathrm{Kà}$ redzams, šeit ir noteikts faktiski identisks pierādīšanas standarts diviem atškirīigiem civiltiesiskās aizsardzības lìdzekḷiem - liguma izpildes prasījumam un civiltiesiskajai atbildībai (zaudējumu atlīdzināšanas prasījumam).

Šajā ziņā nevar nepamanīt prof. V. Bukovska piebildi pie civiltiesiskās atbildības pierādī̌̌anas, norādot “jo viņa pienākums izteicas darbībā”. Atbilstoši CL 1412. pantam saistības priekšmets var būt arī atturēšanās no darbības, t. i., bezdarbība, piemēram, nekonkurēšanas pienākums, konfidencialitātes ievērošanas pienākums u. c. saistības. Diemžēl prof. V. Bukovskis nav norādījis, vai saistības, kuras priekšmets ir bezdarbība, pārkāpums ir jāpierāda pašam prasītājam (cietušajam lìgumpartnerim) vai tomēr arī šeit pierādǐšanas standarts paliek nemainīgs, proti, tas gulstas uz atbildētāju. Ievērojot principu negativa non sunt probanda (negatīvais nav jāpierāda), varētu teikt, ka šādā gadījumā pierādīšanas nasta būtu atstājama uz prasîtāja (cietušā līdzēja) pleciem, jo varētu šḳist netaisnīgi prasīt no atbildētāja pierādīt, ka tas ir atturējies no noteiktas darbības, t. i., ir ievērojis bezdarbību. No otras puses, tiesību literatūrā izteikta atziṇa, ka apstāklis, ka nepieciešams konstatēt negatīvu faktu, automātiski nepārnes pierādīšanas pienākumu. ${ }^{64}$

Autora ieskatā, ņemot vērā līgumisko attiecību specifisku un apstākli, ka vispārēja vainas prezumpcija līgumtiesībās noteikta arī radniecīgajās Vācijas un Šveices privāttiesībās, ${ }^{65}$ kā arī ievērojot, ka "negatīvas" saistības (proti, kuras priekšmets izteicas bezdarbībā) pārkāpuma neesību atbildētājam būtu sevišķi apgrūtinoši pierādīt, tomēr varētu būt apsverama ideja ieviest vispārēju vainas prezumpciju Latvijas līgumtiesībās, ja saistības priekšmets izteicas darbībā. Savukārt, ja saistības priekšmets izteicas bezdarbībā, tad pierādīšanas pienākums būtu atstājams uz cietušā līdzēja pleciem. Šeit jāpatur prātā, ka deliktu tiesībās pēc vispārējā principa pierādīšanas pienākums gulstas uz cietušo arī tad, ja tas tiesību aizskārējam pārmet bezdarbību. Autora ieskatā, saistības, kuras priekšmets izteicas bezdarbībā, pārkāpumu cietušajam līdzējam būtu relatīivi vienkāršāk pierādìt nekā cietušajam delikta gadījumā pierādìt tiesību aizskārēja bezdarbību kā neuzmanību, ievērojot, ka bezdarbības kā saistības pārkāpums jau kā tāds idejiski ir galvenokārt saistāms ar noteiktu aktīvu līgumpārkāpēja rīcību. Tā, piemēram, personai A sniedzot

\footnotetext{
${ }^{62}$ Bukovskis V. 1933, 773. lpp.

63 Turpat, 774. lpp.

64 Ose D. 2015.

65 Sk., piemēram, Looschelders D. Schuldrecht. Algemeiner Teil. 16., neu bearbeitete Aufl. Academia Iuris. Lehrbücher der Rechtswissenschaft. München: Verlag Franz Vahlen, 2018, S. 181; Medicus D., Lorenz S. Schuldrecht I. Allgemeiner Teil. Ein Studienbuch. 21., neu bearbeitete Aufl. München: Verlag C. H. Beck, 2015, S. 154; Schulze R. (Schriftleitung). Bürgerliches Gesetzbuch. Handkommentar. 10. Aufl. BadenBaden: Nomos Verlagsgesellchaft, 2019, S. 366.
} 
pakalpojumus sava agrākā līgumpartnera B konkurentam C, ar aktīvu rīcību (pakalpojumu sniegšanu C) tiek pārkāpta starp A un B pielīgtā nekonkurēšanas saistîba, kuras priekšmets izteicas bezdarbībā. Lìdz ar to šāds pierādī̌anas nastas sadalījums, autora ieskatā, būtu taisnīgs un samērīgs.

\section{Kopsavilkums}

1. Civillikums neparedz vispārēju vainas (neuzmanības) prezumpciju. Tādu neparedzēja arī Baltijas vietējo civillikumu kopojums. Civillikuma 1644. panta pirmās daḷas formulējums šajā ziņā ir maldinošs, un tas prasa precizējumus.

2. Deliktu tiesībās vispārēja vainas (neuzmanības) prezumpcija nebūtu ieviešama. Pierādīšanas pienākums būtu atstājams uz cietušā pleciem, izṇemot, kur likums noteiktos gadījumos paredz vainas (neuzmanības) prezumpciju vai arī stingrās atbildības modeli, kur vainas (neuzmanības) analīzei nav juridiskas nozìmes.

3. Varētu būt apsverama ideja likumdošanas cel̦ā ieviest vispārēju vainas (neuzmanības) prezumpciju līgumtiesībās, ja saistības priekšmets izteicas darbībā. Savukārt, ja saistības priekšmets izteicas kā atturēšanās no darbības, t. i., bezdarbībā, tad pierādīšanas pienākums būtu atstājams uz cietušā līdzēja pleciem. 